\title{
O exemplo de Sócrates
}

The Example of Socrates

\author{
Olímpio Pimenta \\ Professor titular do Departamento de Filosofia \\ Universidade Federal de Ouro Preto [UFOP]
}

\section{RESUMO}

Um tópico de interesse permanente em relação a Sócrates é a determinação dos melhores termos para o entendimento da articulação entre sua vida e sua prática filosófica. $\mathrm{O}$ presente artigo busca ensaiar uma discussão introdutória desta questáo. Nesse sentido, parte-se de uma restituição, em largos traços, do testemunho das três principais fontes diretas, avança-se daí até algumas formulaçóes atuais centradas no tema do exame para, por último, considerar a matéria à luz da morte de Sócrates e dos desdobramentos que seu exemplo quanto a isso ensejou, já no âmbito das escolas helenísticas.

\section{PALAVRAS-CHAVE}

Sócrates; Exame; Vida filosófica; Morte.

\section{ABSTRACT}

An issue that bears continuous interest concerning Socrates is to determine the best terms to understand the link between his life and his philosophical practice. This paper aims to essay an introductory debate about this question. Thus, we begin with a reconstruction, in general lines, of the three main direct sources testimony, go forward from there to some current formulations with respect to the theme of examination to, lastly, review the whole question it in the light of the death of Socrates and of the deployments provided by his example regarding this point, now in the sphere of hellenistic schools.

\section{KEY WORDS}

Socrates; Examination; Philosophical Life; Death. 


\section{Introdução}

Ninguém é indiferente a Sócrates. Nem mesmo ao diletante escapa que este é um dos poucos fatos atestados sem exceção pelas fontes diretas, ${ }^{1}$ discrepantes quanto a quase tudo o mais. Nenhum dentre os contemporâneos do filósofo em condição de se valer do testemunho baseado no contato pessoal ${ }^{2}$ deixa de registrar que sua presença suscita reaçóes intensas naqueles de quem se aproxima, em geral mobilizando nos interlocutores uma grande disposição para responder a interpelaçôes cujo centro é uma espécie de prestação de contas sobre as convicçôes, atividades e condutas que integram sua vida. ${ }^{3}$ Mas importa notar que a relação é recíproca, e que o filósofo se entrega ativamente ao diálogo com qualquer um, ${ }^{4}$ confiante em que não há nada que se possa fazer de melhor nesta vida do que proceder ao exame crítico dos elementos que dão sentido à experiência individual e coletiva, buscando articulá-los à pesquisa da verdade. Ninguém é indiferente a Sócrates: sua exortação dirige-se a todos, pois qualquer um o interessa, e não existe aquele a quem sua prática deixe indiferente.

Seja como for, ao abordar o personagem primordialmente como uma presença envolvente, como um sedutor capaz de atrair a atenção e estimular o engajamento daqueles a quem ele se dirige, talvez tenhamos captado um indício seguro quanto aos motivos da variaçáo nos testemunhos a seu respeito. Quem responde a Sócrates termina por responder a si mesmo, tornando próprias indagaçóes que à primeira vista lhe pareceram alheias. Como mestre sem doutrina, sábio que professa não saber nada, o pensador está longe de figurar entre os demais como modelo de comportamento imediatamente acessível e livre de ambivalências, pronto para ser imitado. Assimilar sua convocação ao pensamento supóe recusar sua condição de autoridade

\footnotetext{
Quanto às fontes antigas, este estudo se concentrou na leitura de Aristófanes (1987), Xenofonte (1987, 20II) e Platão (1997). Dos dois primeiros, nos servimos, respectivamente, de As nuvens e de Ditos e feitos memoráveis de Sócrates, Apologia de Sócrates e Banquete. Quanto a Platáo, partimos da Apologia de Sócrates e de passagens de outros diálogos, a serem referidos pontualmente.

2 As listas de autores que conviveram com o filósofo e escreveram sobre ele, em geral como praticantes do gênero "diálogo socrático", variam bastante, seja em função do estado do material remanescente, seja em função de opçóes metodológicas que não cabe recensear aqui. Combinadas, as versōes de Adorno (1990), Dorion (20II, 2006) e Taylor (20I0) nos dão a ver um espectro amplo, que compreende desde Antístenes e Ésquines, publicistas atenienses voltados para a reflexão sobre a vida política, até Euclides, que se distingue dos demais por força de seu ânimo especulativo, estribado em desenvolvimentos originais da lógica. Conjectura-se ainda sobre a extensão da influência socrática direta sobre Aristipo, responsável pela defesa de uma forma de vida hedonista, bem como restam fragmentos de possíveis diálogos (Alcibiades e Aspásia constam entre seus títulos) atribuíveis a Polícrates, Fédon, Críton, Símias, Cebes e Glauco. Para informaçóes adicionais sobre o ponto, ver Long (1999) e Gottlieb (1999); para uma interpretação bastante original dele, ver Rossetti (2015).

3 É o que se lê, exemplarmente, em Laques a respeito da conversaçáo proposta por Sócrates a seu interlocutor: "[...] de tal modo ele o arrasta na conversa, que o obriga a prestar-lhe contas de si próprio, de que modo vive e que vida levou no passado. Uma vez chegados a esse ponto, não o solta Sócrates sem o ter examinado a fundo" (Platăo, 2015, I87e-188a).

4 Numa veia um tanto ácida, Vlastos diz a este respeito: "Seu apelo é agressivo, o apelo indiscriminado a todo e qualquer um, típico de um pregador de rua. Se você fala grego, está disposto a conversar e a raciocinar, então pode ser parceiro de Sócrates na busca e ter perspectiva que a verdade, não desvendada há tempos imemoriais, pode ser descoberta imediatamente por vocês dois, nos próximos quarenta minutos" (2012, p. 25).
} 
que sabe. ${ }^{5}$ É desconcertante: cada versão a seu respeito lhe empresta forte integridade — seja como cidadão, sofista, sábio, filósofo, herói, mártir ou xamã — ${ }^{6} \mathrm{em}$ bora tais integridades resultem, no mais das vezes, diferentes entre si. Tantas e tamanhas oscilações podem ao menos convergir numa caracterização aberta: Sócrates é um enigma, exigindo de nós, afetados por ele e instados a compreender seu exemplo, trabalho de decifração. ${ }^{7}$

No que se segue, procuraremos desenvolver esta tarefa tendo como grau zero o contexto da Apologia de Sócrates escrita por Platáo, onde se anuncia o programa filosófico segundo o qual uma vida sem exame não é digna de ser vivida. ${ }^{8}$ Embora indeterminada conceitualmente, tal afirmação é categórica ao sustentar que a prática filosófica do exame e a conquista de uma vida boa são indissociáveis. O significado e as implicações disso, entretanto, não são evidentes, demandando algo como um exame dos procedimentos que integram o próprio exame, com vistas a fixar as condiçôes de seu bom funcionamento. Trata-se, assim, de retomar a tradicional questão socrática, buscando atualizar, à luz e à sombra de copiosa fortuna crítica, ${ }^{9}$ os termos em que ela ainda pode ser posta com proveito. Como sempre, entender a ocupaçáo de Sócrates e seus desdobramentos é um caminho promissor se se tem em vista propor uma concepção qualificada do que é a filosofia ela mesma.

A perplexidade que acossava os concidadãos de Sócrates em relação a ele não foi dissipada com o tempo, tendo se transferido para as controvérsias entre os estudiosos ao longo da história. ${ }^{10} \mathrm{Na}$ pesquisa contemporânea, duas concepçóes influentes se contrapóem. Ao voltar a ocupação socrática sobre si mesma, buscando explicitar

5 Ver, a respeito, Assunção (2018).

6 Nos pontos extremos do leque, duas caracterizações notáveis do filósofo, como cidadão sui generis e como feiticeiro, são oferecidas, respectivamente, por Villa (200I) e Grimaldi (2006).

7 Seguimos nisso, literalmente, as caracterizaçóes propostas por Wolff (1982) e Taylor (2010). No capítulo I de seu Sócrates: o sorriso da razão, intitulado "O enigma", Wolff afirma: "Seria bem paradoxal, e até mesmo escandaloso, que, daquele que se esforçou toda vida para resolver os enigmas, esvaziar as lendas e ironizar os mitos, nos tenha restado só um conto da carochinha, bom apenas para fazer sonhar os colecionadores de caricaturas de romance! Fácil de dizer e no entanto... ele escapa ainda entre os dedos do menos ingênuo dos historiadores" (Wolff, I982, p. 13). Já em Taylor, lê-se (2010, p. 9), "Sócrates ocupa um lugar ímpar na história da filosofia. Por um lado, é um dos mais influentes de todos os filósofos e, por outro, um dos mais enigmáticos e menos conhecidos. Além disso, sua influência histórica não é independente desse caráter enigmático".

8 Platão, Apologia de Sócrates, 37d-38a.

${ }^{9}$ Para explicitar a "questão socrática", em cujo registro inscreve-se este ponto, a "vida examinada", adotamos como balizas os escritos de Martens (2013), Rowe (20II) e Dorion (2006). Não há acordo linear entre tais autores quanto aos termos da questão, seja em função da variação em suas estratégias de recepção, seja em decorrência da ênfase dada por eles a aspectos diferentes dos textos compartilhados em sua leitura. A figura de conjunto resultante do cotejo entre suas versóes, contudo, tende a ser consistente: a preocupaçáo com o estabelecimento da verdade do que se alega, destacada por Rowe, náo é incompatível com a transformaçáo na vida de quem se lança ao exame, como pretende Martens, nem com as consequências da dubiedade relativa à afirmaçáo socrática quanto a nada saber, exploradas por Dorion. Desde uma perspectiva eclética, são elementos que se pode incorporar num retrato coerente, cujo eixo será uma formulação clara do enigma, tal como se tenta aqui.

${ }^{10}$ Ao restringirmos o escopo de nossa pesquisa às leituras acadêmicas da matéria feitas entre o final do século XIX e o início do século XXI, entendemos ter agido com prudência. Sem ser especialistas, não reunimos condiçốes para estender a reflexão de forma a incorporar em seu curso o aporte crítico de autores medievais ou modernos. 
seus traços constitutivos, Gregory Vlastos ${ }^{11}$ sustenta que o exame só funciona graças à operação, nele, de uma estrutura metódica invariável, capaz de levar à refutação de uma tese esposada por alguém a partir da dedução de sua contraditória, obtida por apelo a premissas suplementares assentidas pelo mesmo interlocutor. Para lidar com os impasses aí implicados - o esquema provaria apenas incoerência entre teses, mas não sua verdade ou falsidade - o intérprete recorre a conjecturas apoiadas no desenvolvimento posterior do pensamento platônico, a serem examinadas adiante. ${ }^{12}$

Já Monique Dixsaut, valorizando sobretudo os efeitos do exame conexos à educação, vê no seu exercício a senha para a adesão a um modo de vida em que uma racionalidade não dogmática é componente fundamental. De acordo com sua interpretação, o exame proporciona uma abertura real para o desejo de aprendizado e de auto aperfeiçoamento, ao libertar aquele que nele se inicia do jugo das opinióes irracionalmente motivadas. A via para o tratamento filosófico da verdade não se esgotaria na enunciação de regras para provar e refutar, mas teria seu fulcro no reconhecimento das possibilidades e limites do próprio lógos, a serem incorporadas pelos viventes em seu dia a dia. ${ }^{13}$ Sugerir uma combinação justa entre essas duas perspectivas sem simplificar a exigência socrática de retidão intelectual nem descuidar dos compromissos vitais que isso implica é propósito da reflexão que se segue.

\section{Quem é Sócrates?}

Antes de nos ocuparmos em restituir os principais argumentos das duas vertentes interpretativas indicadas acima, remetendo a questão ao debate corrente, é oportuno que nos detenhamos um instante sobre os termos de suas versóes originais. Interessa explorar um pouco mais, à luz de passagens da documentação legada por Aristófanes, Xenofonte e Platão, o fenômeno do carisma socrático, visando a extrair daí elementos que ajudem a esclarecer a ligaçáo entre o que o personagem pensa, como ele atua e quem ele é. À primeira vista irrelevante — o que se ganharia com mais uma tentativa de atinar com nexos táo obscuros, ao invés de concentrar o estudo na explicitação rigorosa do conteúdo dos textos? - , a iniciativa se justifica em nome da decifração projetada. Como já foi sugerido, pode ser que o sentido básico da agência socrática não esteja inteiramente contido nos discursos que a apresentam ${ }^{14}$,

11 "O decano dos estudiosos de Sócrates no século vinte", conforme Matthews (2009, p. I), ao que acrescentaríamos a cláusula, "no mundo anglófono".

${ }^{12} \mathrm{O}$ artigo em que Vlastos (2OI2) consolida sua interpretação sobre o ponto tem um título taxativo, "O élenkhos socrático: método é tudo".

${ }^{13}$ A interpretação de Dixsaut (20I2) é levada a todas as suas consequências no artigo "Refutaçáo e dialética".

${ }^{14}$ Nessa altura manifesta-se um conhecido paradoxo: como ultrapassar o que está nos textos, uma vez que é deles que se deve extrair os elementos para sua ultrapassagem? Não apostando na intuição direta pela via da mística nem confiando apenas na imaginação, faz-se necessária uma espécie de tradução, capaz de incorporar à nossa experiência efetiva as questóes que nos foram dadas pelos textos. No espírito da retidáo, cumpre combinar elementos das várias versóes do personagem com o entendimento discursivo sobre quem fomos antes do contato com ela e sobre quem nos tornamos depois disso. O resultado, como sempre, será um 
mas tenha também a ver com a transformação que produz em seu interlocutor. ${ }^{15}$ Ora, o que exatamente acontece aí, vale dizer, como se dá a injunção por meio da qual somos levados a pensar em nossa vida desta maneira inédita ao topar com o filósofo? Cogitar sobre quem é Sócrates - tarefa impossível na ausência dos testemunhos divergentes sobre ele, mas também impossível sem uma experiência do mundo renovada a partir do contato com esses mesmos testemunhos - pode ser valioso para entender o que entra em questáo a partir de sua intervençáo na cultura ocidental, franqueando o acesso ao coração de sua filosofia - que, assim, talvez se torne nossa também.

Um dos motores do fascínio exercido pelo personagem talvez seja sua curiosidade intelectual, a força de sua boa disposição para pensar bem. Ao frequentar sua conversaçáo, nem os mais impermeáveis, como os soberbos ou os preguiçosos, se recusam a examinar, diante de suas instâncias, as próprias convicçóes, expressas por meio de opiniôes, de modo a conferir se dispóem de fundamento racional defensável. Este ânimo indagativo parece contagioso, pois o movimento que ele desencadeia em busca de razóes capazes de justificar qualquer modo de vida estabelecido quase sempre conta com a adesão dos circunstantes. ${ }^{16} \mathrm{~A}$ prática discursiva socrática promove uma abertura experimental sem precedentes — bem entendido, uma abertura a um tempo teórica e existencial, ligada ao exercício de uma racionalidade a princípio nada abstrata, articulada às atividades e interesses que o interlocutor assume como seus. Na companhia de Sócrates emerge uma demanda nova, o cultivo de uma consciência que é inseparavelmente intelectual e moral e que, sendo assim constituída, aspira a unificar as pesquisas da verdade e do bem.

Se a constatação do nascimento de uma consciência de tipo filosófico junto a Sócrates é comum, sua compreensão é bastante diferente entre os que a reportam em primeira máo. Tendo aparecido cronologicamente antes dos outros, o retrato que Aristófanes faz, em "As nuvens", de um Sócrates entrando na meia-idade, é dedicado a ridicularizar o procedimento e as intençóes do personagem, por ver neles sinais da corrupçáo dos costumes em curso, vinculada ao advento de uma mentalidade irreverente e perigosa para as instituiçóes da cidade. Conservadora em sua orientação geral, a peça visita um "pensatório" para encontrar lá, suspenso num cesto entre o céu e o chão, um sujeito devotado, por um lado, a investigar a natureza

amálgama entre texto e mundo, criação que deve ser submetida a exame dialógico para teste de sua força e de sua verdade.

15 No dizer de Hadot, trata-se da "experiência extraordinária que representa o encontro com uma personalidade incomparável” (2014, p. 108).

${ }^{16}$ Provavelmente contribui para tanto a convicçáo pessoal generalizada de que cada um dispóe de razão em medida suficiente - ou, conforme Descartes, "cada um pensa estar táo bem provido que mesmo aqueles mais difíceis de se satisfazerem com qualquer outra coisa não costumam desejar mais bom senso do que têm” (2007, p. 5). 
sem recorrer aos deuses e, por outro, a ensinar a impostura argumentativa. A ausência de deuses em um mundo atravessado pela guerra, ${ }^{17}$ no qual a palavra circula sem restriçóes, parece ocasiáo perfeita para o esvaziamento da autoridade e a recusa da tradição, culminando num processo de deriva valorativa.

Não obstante o caráter decididamente cômico do texto, é provável que o dramaturgo não tenha acertado em cheio seu alvo. A curiosidade socrática não implica a impiedade porque não se subordina aos objetivos de uma investigação científica de extração naturalista, geralmente associada à suspensão do juízo sobre matéria religiosa. Ao contrário, um efeito lateral da implementação do exame crítico é a oferta de um horizonte de legitimação discursiva a este gênero cultural ainda incipiente. Sócrates respeita a ciência, tendo inclusive se iniciado nela, mas percebe, talvez na mesma medida em que seu primeiro detrator oficial, que algumas dimensões da experiência humana se acomodam mal a uma pesquisa em seus moldes. De mais a mais, o saber científico deve ser testado segundo critérios empíricos e sua transmissão é positiva, isto é, ocorre entre um que sabe e outro que não, requerendo a existência de comunidades que compartilhem uma dogmática mínima. Não existe conciliação possível entre uma honesta alegação de ignorância por parte de Sócrates ${ }^{18}$ e o ensino de técnicas cuja chancela última depende de pressupostos indiscutíveis e de resultados concretos. O plano do conhecimento técnico empiricamente testado não é aquele em que o pensador nos exorta a entrar.

Entrementes, todos sabemos que a acusação de impiedade se firmou ${ }^{19}$, obrigando Sócrates a se apresentar diante do tribunal, evento que resultou em sua condenação à

\footnotetext{
${ }^{17}$ No caso, trata-se da guerra do Peloponeso, em pleno andamento em 423, ano em que As nuvens foi representada pela primeira vez no festival dedicado a Dioniso.

${ }^{18}$ A declaração de ignorância por parte de Sócrates é ponto de vivo debate entre os especialistas. Entre as dúvidas que permanecem em aberto, importam-nos as seguintes: o que busca aquele que náo sabe? Como reconhecer que encontrou o que buscava, se não sabia de antemáo o que isso é? De acordo com Matthews (2009, p. 5 , grifos do original, tradução nossa), "Da evidência dos primeiros diálogos, parece que o que Sócrates requer como uma resposta adequada à sua questão 'O que é F-idade?' é um determinado conjunto de condiçôes necessárias e suficientes para algo contar como $\mathrm{F}$. $\mathrm{O}$ conjunto de condições necessárias e suficientes não pode ser composto apenas por características que costumam pertencer somente a todas as pessoas e coisas que sejam F; eles devem revelar aquilo pelo qual x é F — isto é, o que faz de x F. Para colocar o ponto de outra maneira, eles devem revelar a natureza (ousia) do que é ser F (Euthyphro ira)". Mesmo que o exame náo leve ao atendimento dessas condiçóes, elas podem permanecer como seu horizonte. Nesse sentido, Sócrates ao mesmo tempo sabe qual é a melhor questão a propor, embora năo saiba a melhor resposta, mantendo-se ignorante, juntamente com seus interlocutores, mesmo na posse de algum resultado "positivo" do exame. O "conhecimento por definição" talvez seja mesmo um horizonte, área de alcance cujos limites se modificam sempre que nos lançamos a explorá-la.

${ }^{19}$ Eximindo-nos de maiores elucubraçóes sobre o contexto da acusação, transcrevemos a seguir a concisa exposiçâo de Taylor a este respeito: "Em algum momento do ano 400 ou bem no começo do ano 399, um jovem obscuro chamado Meleto (Eutifron, 2b) fez contra Sócrates a seguinte acusação: 'Meleto, filho de Meleto de Pitos, apresentou e juramentou esta denúncia contra Sócrates, filho de Sofronisco de Alopece: Sócrates é culpado de náo reconhecer os deuses que a cidade reconhece e de introduzir novas divindades. É culpado também de corromper a juventude.' Dois outros tiveram parte na acusação: Licon, também desconhecido, e Anito, um político de destaque na democracia restaurada. Após um inquérito preliminar [...] diante do magistrado que se encarregava dos casos religiosos, conhecido como rei, o caso foi a julgamento diante de um júri de quinhentos cidadáos, no início da primavera de 399” (2010, p. 20).
} 
morte. Se tal acusaçáo pode ser reconhecida como improcedente em vista do que foi alegado acima, um argumento suplementar encaminha a defesa de maneira mais convincente. A iniciativa a favor do filosofar se consolida como reação ao proferimento da Pítia, segundo o qual não existiria homem mais sábio do que Sócrates. ${ }^{20}$ Imprimindo uma torção à leitura espontânea do ponto, que implicaria aceitar sua sabedoria como dada - uma espécie de repositório disponível para consulta direta —, o personagem entende melhor o dito da sacerdotisa como uma convocação. ${ }^{21}$ Desde entáo ele teria passado a interpelar todos os que eram reputados como sabedores de seus ofícios, tentando extrair daí definiçôes suficientes do que é o saber que lhes garantiria tal reconhecimento. Inicia-se, assim — inspirado por uma sentença oracular, embora dotado de jurisdição própria —, um processo sem precedentes de inspeçáo global do conhecimento humano. Por seu intermédio, reivindica-se que o destino do sábio não se consuma na coleçáo das produçóes objetivas da ciência nem na admissão cega de algo chancelado pelos deuses. Náo se impóe a ele obediência nem se espera dele adesão ao que funciona graças ao domínio técnico de alguma porção da realidade. Seus compromissos abrangem o exame do que se toma por bem e verdade, e para isso náo basta afirmar as próprias convicçóes, sejam elas dogmáticas ou empíricas.

Embora assinale a disponibilidade de Sócrates para a livre investigação, a imagem do pensador que aparece nos Memoráveis de Xenofonte resulta também suscetível a ponderaçôes quanto a sua plausibilidade. Eminentemente prosaico, este Sócrates é descrito como alguém consagrado a obter o útil para si e seus concidadáos. ${ }^{22}$

\footnotetext{
${ }^{20}$ Se a maré montante contra Sócrates já se deixa perceber em Aristófanes (1987), que inclusive se refere em várias passagens ao discípulo Querefonte (por exemplo, v IO4; I44-I45; I56; 502), é Platâo quem apresenta "oficialmente", anos mais tarde, um motivo central do desfavor do público em relação a seu mestre: a atribuição, a ele, da reputação de sábio. Lemos na Apologia, 2ıa: "Sabeis como era Querefonte, a paixão que punha em tudo que empreendia. Ora, tendo um dia ido a Delfos, ousou consultar o oráculo sobre a seguinte questáo - peço-vos mais uma vez, atenienses, que näo comeceis a clamar contra o que eu vou dizer -: perguntou se havia alguém mais sábio do que eu. A Pítia respondeu-lhe que não havia ninguém mais sábio" (1997, p. X, grifo nosso).

${ }^{21} \mathrm{Na}$ mesma direção, lê-se em Gottlieb (I993, p. 20): "Suas referências pias à sabedoria de Deus (às vezes, se refere a um único Deus, outras, a deuses) são aptas a encobrir o quanto sua atitude para com a divindade era pouco convencional. Quando diz que apenas Deus possui sabedoria, parece estar querendo dizê-lo figurativamente, do mesmo modo que alguém pode dar de ombros e dizer 'Deus é quem sabe'. [...] Uma vez introduzido ao pronunciamento divino de que nenhum homem é mais sábio do que Sócrates, ele se recusa a atribuir-lhe de imediato um valor, até ter a certeza de que um verdadeiro sentido possa ser aí encontrado".

${ }^{22}$ Entre tantas passagens afins, lê-se por exemplo que "Tão útil era Sócrates em todas as ocasiôes e de todas as maneiras, que até as inteligências medíocres facilmente compreendiam nada haver mais vantajoso que seu comércio e frequentação" (Xenofonte, 1987, Livro IV, capítulo I, I et seq.); ou então "Por Sócrates confundido, Aristipo esgorjava por confundi-lo. Mas Sócrates, desejando ser útil a seus ouvintes, não respondia à luz de quem traz o olho sobre o ombro e receia lhe refertem as palavras, porém, como homem convicto de que cumpre seus deveres" (ibid. Livro III, capítulo VIII, I et seq.). Ora, a determinaçáo conceitual do útil e da natureza dos deveres cívicos, e também o apelo direto ao cálculo de vantagens como medida de valor das condutas, demandariam um exercício crítico que está ausente aqui.
} 
Nesse sentido, ele busca persuadir e aconselhar, transmitindo doutrina e dando liçóes, provando-se companhia vantajosa para todos. ${ }^{23} \mathrm{O}$ quadro das virtudes tradicionais forma o cenário onde ele se movimenta, e disso se segue seu alinhamento aos ditames de uma moralidade convencional, comprometida acima de tudo com o bom senso e a prudência. ${ }^{24}$ Esse campeáo da utilidade teria cumprido um trajeto isento de ambiguidades, provendo aos demais, através de seu exemplo efetivo, o modelo palpável de uma vida bem vivida.

A maior dificuldade enfrentada por essa visão de Sócrates está em que seus pressupostos coincidem com os que são atribuídos, de modo muito vívido, a adversários notórios do pensador, agora no âmbito dos diálogos platônicos. Entre inúmeros exemplos, cabe apontar que a prática de beneficiar os amigos e prejudicar os inimigos, reivindicada por Xenofonte como eixo da atuação socrática, está em conflito diametral com o que se lê no Livro I de $A$ República. O cotejo entre as duas versóes não favorece o relato do historiador. Não é cabível supor que a discussão sobre a vida boa possa ser reduzida a um virtual emparelhamento das diferentes opinióes a seu respeito, negligenciando-se a crítica de seus fundamentos. A admitir-se ser Sócrates tal como Xenofonte o percebeu, sua relaçáo com um tipo feito o sofista Trasímaco, que figura com destaque na passagem platônica mencionada, seria de simetria e equivalência - como se restasse a Sócrates apenas negar o que o interlocutor afirma, construindo seu discurso como o contrário do discurso do outro, mantidas intactas suas bases. A trivialidade de um embate assim impede que se entenda a dimensão tomada pelo vulto de Sócrates. Como poderia um homem, definido em última análise por sua simplicidade e sensatez, desafiar durante séculos a inteligência geral, suscitando reaçóes tão apaixonadas quanto conflitantes entre si?

Se o que se disse até aqui confirma a presunção de que cada um pinta um Sócrates à altura de si mesmo, o monumento erguido por Platão a seu mestre merece atenção

\footnotetext{
${ }^{23}$ Nesse sentido, lê-se que "De mim penso que os que praticam a sabedoria e se crêem capazes de dar conselhos úteis a seus concidadãos de modo nenhum são violentos, visto saberem que a violência atiça o ódio e acarreta perigos, enquanto a persuasão elimina os riscos e não prejudica a perfeiçáo" (ibid., Livro I, cap. II, Io); e também que "[Sócrates] abrigava a certeza de ganhar, naqueles que lhe seguiam os princípios, bons amigos, que o amariam e se estimariam reciprocamente para o resto da vida" (ibid., 8). Conselhos, princípios e persuasão integram um vocabulário difícil de compatibilizar com as exigências radicais do exame filosófico, não obstante seu imediato proveito instrumental no interior de uma moralidade convencional. À primeira vista parece virtuoso aconselhar a coragem, mas exercê-la sem conhecimento do que ela é significa proceder como o general Laques, que age segundo convicçôes e é reconhecidamente corajoso, embora não alcance justificar suas açôes por meio de razóes suficientes.

${ }^{24} \mathrm{~A}$ imagem do pensador que se infere do Banquete é um tanto diversa disso. Mostrando um Sócrates muito à vontade entre os amigos, a narrativa salienta seu lado espirituoso e sua bonomia. A difícil questáo do exame é ali abordada segundo uma analogia insólita que, se não honra a estatura epistemológica do assunto, em contrapartida lhe provê enraizamento experimental. Depois de definida a igualdade entre mulheres e homens quanto à capacidade de aprender, Antístenes pergunta a Sócrates por que ele não havia educado ainda sua esposa Xantipa, recebendo a seguinte resposta:" Sabes, é que eu tenho-me apercebido que os que querem chegar a bons cavaleiros não procuram os cavalos mais dóceis, mas o mais impetuosos; acreditam que se conseguirem domar estes, lidarâo mais facilmente com todos os outros cavalos. Ora, eu, que quero conviver e conversar com pessoas, casei com ela, porque estou certo de que, se conseguir aguentá-la a ela, facilmente conseguirei conviver com qualquer pessoa" (Xenofonte, 20II, IO, grifos nossos).
} 
especial. Decerto a obra platônica nos mostra também um personagem curioso e disposto a pensar sem descanso os temas que explora, nisso convergindo com a impressão dos demais. Mas há muito mais ali. ${ }^{25}$ Sem querer resolver um problema insolúvel, discernindo o que é devido a um e a outro nos diálogos, cumpre sublinhar a sofisticação que preside as sucessivas participaçôes de Sócrates no corpus platônico. O caráter extraordinário da atitude existencial e das intervençôes teóricas socráticas é patenteado por toda parte nesses escritos, prevenindo o leitor contra uma concepção singela dos poderes do personagem. Demonstrando o gênio do discípulo, isso reabre, em contrapartida, a questão sobre o gênio do mestre. Se tanto "As nuvens" quanto os "Memoráveis" trazem à cena personagens até certo ponto banais - um Sócrates espertalhão e outro razoável em demasia —, os talentos do terceiro escritor nos representam um tipo complexo e admirável.

Se se chega a imaginar que, por força de sua curiosidade, Sócrates era um indivíduo inquieto, promotor do inconformismo, Platão logo nos inclina em contrário. Longe da agitação de gente assim, o desenho de Sócrates que dele se depreende irradia uma firmeza tranquila e bem humorada. Seu trato é jovial, sem perder a seriedade, e seu ânimo está sempre sereno, alerta e disponível. ${ }^{26} \mathrm{O}$ enigma se complica: é alguém com quem queremos privar, alguém que nos atrai, mesmo quando nos importuna, desestabiliza e faz cismar. Diante dele coloca-se a pergunta sobre a origem e a natureza dessa dupla disposiçâo, que combina a calma de quem irradia segurança com o ímpeto de quem está pronto a examinar sem reservas o que quer que seja. Para os curiosos como ele, é difícil não se lançar em busca do segredo de quem consegue lidar de forma harmônica com tendências normalmente muito conflitantes.

Sem investir-se do papel de autoridade, Sócrates prescinde da arrogância que costuma acompanhar os que se consideram dotados de saber. Sem pressa, observa seu interlocutor, esperando a oportunidade certa para fazer algo como uma semeadura. ${ }^{27}$ Aos seus olhos treinados, o encontro com a dúvida é inconfundível. Ele presencia o espanto de seu conviva, uma espécie de euforia pânica. Questóes urgentes tomam conta deste, que pensa então: e se tudo for diferente do que acreditei até agora? E se o que sei com certeza náo for o caso? Exercitando a disposiçáo adequada,

${ }^{25}$ Os estudos que serviram de preparação para este escrito muita vez contribuíram para confirmar a sentença de Whitehead a respeito das relações entre a história da filosofia ocidental e o pensamento de Platão. Várias tradiçóes interpretativas visitadas parecem subsistir apenas à sombra de Platấo — sendo, talvez, a própria sombra de Platão. Em todo caso, sempre se pode preferir combater à sombra.

${ }^{26}$ Pelo menos quanto a isso duas fontes coincidem, pois lê-se também no Banquete de Xenofonte (20II, IV, 29), depois que o arremate de uma disputa termina em galhofa: "E era assim que as brincadeiras se misturavam com as conversas sérias".

${ }^{27}$ A imagem, que remonta ao Fedro de Platáo (277a), foi aqui tomada de empréstimo a Adorno (1990), que a desenvolve de forma magistral no primeiro capítulo de seu Sócrates, obra que se inicia exatamente com considerações sobre "As sementes de Sócrates". Sob sua luz, as diferenças e eventuais incongruências entre os mais diversos Sócrates encontram um equacionamento abrangente e plausível: tratar-se-iam das diversas brotaçôes possíveis em presença de condiçōes muito variáveis de plantio, tais como as portadas pelos incontáveis viventes tocados por Sócrates. 
talvez não precise mais ter medo do que supunha certo, podendo dispensar os expedientes empregados até aqui para prevenir o sofrimento e para assegurar validade às minhas escolhas. Devo me pôr a caminho para aprender aquilo de que até então nem desconfiava. Não sei sequer o que reserva a morte, única certeza absoluta do vivente. Ganho assim a coragem de me apresentar frente aos desafios que aparecem, sendo o mais importante deles revestir de dignidade racional minha própria trajetória pessoal. Fazendo as contas, qualquer arrogância não passava de sintoma de ignorância sobre a própria ignorância, e finalmente — graças ao dom socrático - estou em condição de me livrar desse estado miserável. ${ }^{28}$

É claro que o exposto até agora não assegura o necessário para determinar em que consiste o ensinamento socrático ou qual é a natureza do conhecimento que ele provê. Mas ao menos duas margens de exclusão foram estipuladas: não se trata da transmissão de um estoque de conhecimentos acumulados de antemáo e nem da aceitaçáo de verdades cuja chancela estaria numa procedência acima de disputas humanas - fossem tais verdades de ordem artística ou religiosa. Através de Platão, o que chega de Sócrates para nós é um convite para fazer filosofia. Resta estender o exame dos significados disso, como se buscará na sequência.

\section{Sobre o exame}

Em que consiste o programa filosófico socrático, considerados os delineamentos esboçados na "Apologia" platônica? O que significa, em seus termos, pensar bem? Retomemos o ponto, ainda segundo noçóes triviais. De um lado, impóe-se formular com clareza o tema visado e apropriar-se dele desde o ângulo correto, dispondo dos procedimentos adequados para triar, dentre os encaminhamentos possíveis, o que melhor serve à demanda por inteligibilidade — aspecto teórico nuclear do processo. De outro lado, impóe-se entender a incidência do exame sobre as condutas e os assuntos já em andamento, aplicando as consequências do que foi apurado às performances articuladas ao que se dizia antes sem pensar direito - sendo este o aspecto vital nuclear do processo. Cumpre acrescentar que a circulação funciona em mão dupla, e assim o que se experimenta depois do pensamento o realimenta, propondo a ele novos motivos, numa espécie de espiral ascendente.

Embora defensável no papel, esta declaração de princípios esbarra em dificuldades táo logo se apresenta. Os critérios e condiçóes para ajuizar sobre clareza, correção e adequação, e também para reconhecer segundo boas razões os vínculos entre o

\footnotetext{
${ }^{28}$ Ao se estender sobre "O sentido de nossa jovialidade", matéria do aforismo 343 de um livro dedicado à modalidade mais atraente de saber, A gaia ciência, Nietzsche cogita sobre disposiçóes correlatas à que foi sumariada: “[...] De fato, nós, filósofos e 'espíritos livres', ante a notícia de que 'o velho Deus morreu' nos sentimos como iluminados por uma nova aurora; nosso coraçáo transborda de gratidão, espanto, pressentimento, expectativa - enfim o horizonte nos aparece novamente livre, embora não esteja limpo, enfim os nossos barcos podem novamente zarpar ao encontro de todo perigo, novamente é permitida a nós toda ousadia de quem busca o conhecimento, o mar, o nosso mar, está novamente aberto, e provavelmente nunca houve tanto 'mar aberto"” (2009, p. 234).
} 
pensado e o vivido exigem, por sua vez, esclarecimento justificado. Antes mesmo de começar, parece que obstáculos intratáveis embaraçam a empresa do pensamento. Como se isso não bastasse, no fundo da investigação subjaz a dúvida sobre que concepçôes valem acerca do bom e do melhor, parâmetros gerais para a confirmação da validade do que se afirma. Mas o fato é que se pensa, e a grande maioria acha que pensa como deve — incluídos aí os adversários da filosofia.

Uma estratégia promissora para a retomada da questão é concentrar o esforço na explicitação de regras para o desenvolvimento do exame, outro nome para o pensamento em ação. Nessa direção, a busca pela definição de um padrão lógico universal situa a dimensão metodológica do problema em primeiro plano. Havendo mecanismos invariáveis para marcar a diferença entre o bom e o mau caminhos do pensamento seria possível indicar com que caso Sócrates se alinha.

Num terreno marcado pela dissensão, é um alívio que o primeiro passo conte com reconhecimento consensual. Ao menos no que concerne aos diálogos platônicos ditos de juventude ${ }^{29}$, uma cláusula preparatória é onipresente. Ao buscar saber o que até ali se ignora, cumpre rejeitar a candidatura das opinióes como resposta adequada. Desinteressada em ou incapaz de dar de si razóes suficientes, a opiniáo é atrelada ao curso das paixóes, podendo ser trocada à medida em que seu portador seja persuadido de que isso é o que lhe convém. Isto acontece porque o jogo das opiniōes não é interditado pela contradição, uma vez que, em seu curso, é pertinente opinar a favor e contra qualquer posição alegada sem que seja necessário mobilizar provas duras para tanto - afinal, para consolidar uma opinião qualquer, o que conta é suscitar no público ou a confirmaçáo ou a mudança de determinada tonalidade afetiva. Uma consulta ao final do debate permite contar os votos e decretar qual é a opinião vitoriosa, sem que se conclua se ela é a melhor de direito. ${ }^{30}$ O incrível é que, até a chegada de Sócrates, ninguém objetava a sério diante de circunstâncias tão incertas - e que, tantos séculos depois dele, a opiniáo siga sendo instância decisória para a maioria das questôes públicas. ${ }^{31}$

${ }^{29}$ Advertidos sobre as controvérsias que minam o terreno, acatamos uma periodizaçáo escolar para os diálogos de Platão, presente em Reale e Antiseri (I990, p. I27 et seq.). Baseada na estilometria e no desenvolvimento temático do pensamento platônico, esta classificação inclui, entre os escritos de juventude cuja autoria não é mais disputada, além da Apologia, os diálogos Eutífron, Criton, Carmides, Laques, Lisis, Íon, Menexeno, Hipias maior e Hipias menor — náo necessariamente nesta ordem.

${ }^{30}$ Nesse sentido, lê-se em Piettre: "Cada um tem sua opiniáo sobre esta ou aquela questáo e a ela se encontra, em geral, particularmente preso. Ter uma opiniáo é emitir um parecer, um juízo sobre um ou outro tema. Ora, as instituiçóes da democracia ateniense repousam por direito sobre o reconhecimento do valor e da legitimidade das opinióes de cada um, seja pobre ou rico, ignorante ou sábio. Platáo recusa-se a admitir esse fato. Nega-se a pensar que a política possa ser questão de opinião e não de saber e, nesse sentido, opóe-se a Protágoras e aos sofistas em geral" (I996, p. 22). É digno de nota que, variando em funçáo do saber ou de sua ausência, o que é "de direito" náo siga o que é "de fato", mas deva se impor sobre ele, sempre a partir de razóes examinadas.

31 Apresentado como criador de uma concepção alternativa de cidadania, proposta em nome de uma integridade moral e intelectual filosoficamente instruídas, o Sócrates reconstruído por Villa milita em prol do direito à dissidência e à crítica. De acordo com isso, por meio do exame é gerada uma "espécie de esfera pública alternativa" (200I, p. xii, tradução nossa), na qual os critérios para o ajuizamento fundamentado não são 
As primícias da novidade trazida pelo filósofo estáo ao alcance de todos, como prova o sem número daqueles que aceitam discutir com ele. Seu extrato pode ser condensado assim: ao invés de procurar o saber na qualificação do jogo das opiniôes, Sócrates propóe uma depuração racional da experiência através de uma "conversão da inteligência". ${ }^{32}$ Trata-se, com ele, de investigar dimensôes da realidade que não se confundem com aquela descrita apenas com base no depoimento dos sentidos e em seu lastro passional. Mais: trata-se de perguntar o que é que é aquilo com o que verdadeiramente nos ocupamos quando dizemos que tal coisa é assim ou assado. Melhor ainda: trata-se de procurar o que permite que digamos o que é tal coisa, aquilo que confere a ela uma identidade essencial. Infinitas ocorrências da coragem em ato não se prestam a definir o que é a coragem, nem a produzir seu conceito. É defensável que, no plano estrito da teoria, o exame socrático pretenda justamente isso.

$\mathrm{Na}$ tentativa de deslindar as implicaçóes de tal pretensão, a posição construída por Vlastos se destaca, como dito anteriormente. Tomando suas referências principais junto ao quadro do pensamento aristotélico, ${ }^{33}$ ela sustenta que um resultado negativo do exame, constatado quando os discursos que se candidatavam a responder à questáo proposta por Sócrates são refutados, presume uma contrapartida positiva, o que, por sua vez, demandaria aporte especulativo ponderável. Grosso modo, o procedimento padrão do exame poderia ser enunciado conforme as quatro etapas seguintes. Parte-se de uma tese afirmada pelo interlocutor de Sócrates, a que em seguida se acrescentam algumas premissas adicionais, dependentes de contexto específico, também assentidas pelos envolvidos no diálogo. Importa sublinhar que essas premissas adicionais não são admitidas em função de sua reputação junto ao público douto, ou mesmo junto à maioria, mas dependem apenas de acordo entre os interlocutores. Sócrates então prova a ele que o desenvolvimento de tais premissas leva à afirmação de outra tese cujo conteúdo contradiz o da tese inicial. Diante disso, resta um problema: os interlocutores devem concluir que a refutação da tese inicial prova sua falsidade, bem como a verdade de sua contraditória, ou apenas que as teses inicial e adicionais não exibem coerência entre si? Se nos ativermos aos passos da argumentação tal como ela foi restituída, ficamos restritos à verificação de inconsistência, mas não temos elementos para avançar até a prova da verdade.

"persuasão, decisão ou açáo, mas a aplicaçáo da escrupulosa honestidade intelectual (e ironia) aos fundamentos 'indiscutíveis' da cultura moral de sua cidade” (Ibid. ).

32 A expressão, cunhada por Piettre, aparece no comentário já citado (p. 36).

${ }^{33}$ Para efeito de seu raciocínio, o autor recorre aos Tópicos (Iooa27-bı), de onde toma a definição de demonstraçáo, empregada para discernir, na segunda etapa do "élenkhos padrão", a natureza das premissas adicionais propostas por Sócrates a seu interlocutor. A peculiaridade do método socrático estaria em avançar a argumentação "a partir das crenças do respondedor" (Refutaçóes sofísticas, I83b7-8), não apelando a verdades autoevidentes, como no caso dos raciocínios demonstrativos, "tribunal de última instância para decidir discordâncias filosóficas" conforme Aristóteles (Vlastos, 20I2, p. 36). Tal peculiaridade permite ao intérprete alavancar sua principal reivindicação, a de que Sócrates busca a verdade exclusivamente no terreno moral. As razóes de nosso desacordo quanto a esta restriçáo estáo disseminadas ao longo da presente exposiçáo. 
No âmbito dos diálogos platônicos de juventude, ainda segundo Vlastos, para passarmos da prova da inconsistência interna de um determinado corpo de teses à prova da verdade de alguma tese, uma série de novas ideias devem comparecer. E, com efeito, ele entende que elas já estão lá, embora tenham sido negligenciadas por sucessivas geraçóes de leitores. ${ }^{34} \mathrm{~A}$ pedra de toque, que funcionaria como referência fixa para a apuraçáo da verdade e de seu contrário, seria a aposta socrática na existência de um fundo de crenças morais verdadeiras acessíveis a todos. ${ }^{35}$ Este Sócrates acredita que, qualquer que seja o conjunto de premissas adicionais, sempre será possível refutar uma tese que náo corresponda a esse fundo comum. Haveria, portanto, ainda que latentes, verdades básicas, sobre as quais caberia uma investigaçáo "metaelêntica", que obviamente não foi tentada pelo filósofo. ${ }^{36}$ Obviamente, pois seu método já teria levado à constatação, reiterada diante dos mais diferentes interlocutores, de que "o conjunto de crenças morais testadas elenticamente e sustentadas por Sócrates em um momento dado é consistente" ${ }^{37}$ Assim, enquanto que, para este Sócrates, deve haver "um fundo de crenças morais verdadeiras implícitas em todo homem capazes de refutar suas crenças falsas" (Mafra \& Marques, 20I2, p. 8), em Platáo o pensamento teria evoluído até atinar com a teoria "ultraespeculativa" da reminiscência, apta a explicar a proveniência daquelas crenças morais verdadeiras. O inconveniente é que esta versão da prática socrática força a distinção entre as realizaçôes do filósofo e as de seu principal discípulo, abrindo um hiato entre a especulação sobre o ser e a verdade e o inquérito moral, além de desafiar a noção, ainda muito convincente, de que a alegação de ignorância por parte de Sócrates é procedente.

Digna da maior atenção, a alternativa de Dixsaut ao que foi sumariado acima repousa sobre um entendimento lúcido da distinçáo entre o que pode ser entendido por positivo e negativo no âmbito das investigaçóes socráticas. De acordo com a intérprete, sempre positivas são as opiniōes a favor ou contra algo, enquanto que o saber é uma atividade ou estado aberto, passível de acréscimo e revisão constantes: "Se o saber é interior a uma alma que só consegue conhecer um ser ao interrogar-se sobre o que ele é e ao inventar os meios de responder a sua questão, o saber não é,

${ }^{34} \mathrm{O}$ cavalo de batalha do intérprete encontra-se em Górgias, 479e: "Não foi provado que o que foi afirmado [por mim mesmo] é verdadeiro?".

${ }^{35}$ Assim, lê-se que "Temos aqui uma evidência conclusiva a favor da convicção de Sócrates: ele acredita que quando mostra a seus interlocutores a inconsistência de suas teses com relação ao conjunto de premissas às quais deram assentimento, eles nunca conseguirão salvar suas teses retirando uma ou mais das premissas admitidas. Se tentarem salvar suas teses dessa maneira, fracassarão, independentemente de quais premissas recusarem, pois haverá sempre outras premissas em seu sistema de crenças que acarretarâo a tese socrática. Sócrates, então, está fazendo uma tremenda suposiçāo. Dita de modo geral, significa o seguinte: [A] Quem quer que tenha uma crença moral falsa terá sempre, ao mesmo tempo, crenças verdadeiras que acarretam a negaçáo dessa crença falsa" (Vlastos, 20I2, p. 47).

${ }^{36}$ Afinal, segundo Vlastos, "Em cada um dos diálogos anteriores ao Mênon, Sócrates preserva sua inocência epistemológica e sua ingenuidade metodológica, admitindo que tem o método certo para buscar a verdade moral, mas nunca tentando justificar a suposição" (2012, p. 48).

${ }^{37}$ Esta é a suposição $[\mathrm{B}]$, que combinada com a suposição [A], permitiria a passagem da refutaçấo de teses inconsistentes à prova da verdade de uma tese. 
nele mesmo, nem negativo nem positivo, mas interrogativo e inventivo" (Dixsaut, 20I2, p. 85). O tudo ou nada imaginado como mecanismo do procedimento socrático não parece corresponder ao que o personagem fazia, como atesta a abundante documentação reunida pela intérprete. ${ }^{38} \mathrm{Em}$ suma, segundo ela o exame não propóe a refutação de proposiçóes isoladas e nem tem seu sentido garantido pelo recurso a proposiçóes isoladas, mas se volta para o combate das origens mesmas da opiniáo, enraizadas na crença lamentável de que se sabe quando não é este o caso.

Nesta linha, retoma-se o espaço do exame como um espaço de interrogação e invenção, onde a saída para as aporias firmadas por meio de refutação é plural. Semelhante concepção reafirma a continuidade entre as reflexóes socrática e platônica $^{39}$ — de resto dificilmente discerníveis em definitivo — , bem como restaura a contiguidade entre o terreno da moral e os domínios vizinhos da epistemologia e da metafísica, contribuindo para a manutenção do interesse pela simultaneidade dessas mesmas reflexóes entre nós. O engajamento moral é um elemento indispensável do exame porque as transformaçóes operadas na vida de quem o pratica convocam a pesquisa da verdade para o plano da efetividade, que é aquele em que, querendo ou não, estamos agora. De mais a mais, pensar segundo a verdade náo pode ser diretriz exclusiva de qualquer campo específico da filosofia, condição que é para sua existência mesma enquanto filosofia. Não custa insistir em que "saber", para Sócrates, não é deter um conjunto coerente de proposiçôes verdadeiras, mas adquirir uma consciência reta e intransigente da própria ignorância, ponto de partida para o advento de uma atitude disponível em relaçáo à pesquisa na e da verdade. ${ }^{40}$

Parece, assim, que o exame realiza uma purificaçáo espiritual em quem dele participa, ao expurgar a ignorância de seu corpo e das preferências que moram nele,

\footnotetext{
${ }^{38}$ A um que se inicia nos estudos clássicos, impressionou a desenvoltura exibida pela autora no tratamento dos corpora platônico e aristotélico. Nada menos do que onze diálogos, das três fases da produção platônica, são citados em sua exposição, sempre no lugar e na hora mais oportunos. Por outro lado, seu uso das fontes aristotélicas é mais exaustivo do que o do próprio Vlastos, a quem se dirige sua contundente réplica.

${ }^{39}$ Se isso é assim mesmo, a própria continuidade entre os compromissos filosóficos de Sócrates e Platão é confirmada nos termos seguintes: "O que ele [Platáo] sempre conservou de Sócrates, é que todo saber verdadeiro tem por princípio a consciência de náo saber, pois apenas essa consciência pode ser a origem do desejo de aprender. Isso é suficiente para suprimir o caráter doxástico do que se diz, pois, para aquele que sabe que náo sabe, a verdade torna-se ao mesmo tempo objeto de desejo e de busca, ela não é a posse de alguns enunciados e, diferentemente do verdadeiro que tem por contrário o falso, que só pode ser dito da opinião, a verdade não tem contrário, ela é o 'elemento' no qual se move um saber que, nele mesmo, jamais pode ser falso (um saber que pode apenas errar o seu fim)" (Dixsaut, 20I2, p. 84).

${ }^{40}$ Em acordo com isso, o Nietzsche de $A$ gaia ciência afirma, no aforismo 2, intitulado "A consciência intelectual": "Continuo tendo a mesma experiência e me rebelando igualmente sem cessar contra ela, não desejo acreditar nela, ainda que me seja palpável: a grande maioria das pessoas não têm consciência intelectual; e frequentemente quis me parecer que se alguém a exige, nas mais populosas cidades, acha-se táo só como no deserto. Cada qual olha para você com olhar estrangeiro e prossegue no uso da sua balança, chamando a isso de bom e àquilo de mau; ninguém se enrubesce, quando você dá a entender que os pesos náo estáo justos tampouco há indignaçáo contra você: talvez riam da sua dúvida. Quero dizer: a grande maioria não acha desprezível acreditar isso ou aquilo e viver conforme tal crença, sem antes haver se tornado consciente das últimas e mais seguras razóes a favor ou contra ela, e sem mesmo se preocupar depois com tais razóes — [...]" (Nietzsche, 2009, p. 54, grifos do original).
} 
interditando ali a vigência das opinióes, sempre positivas enquanto tais, e abrindo espaço para experimentaçóes dialógicas compatíveis com a orientação que ele oferece. Não cauciona em abstrato a validade de produçóes discursivas, como pretendem os partidários de um Sócrates metodólogo, mas franqueia a procura dos critérios para tanto. Segundo essa função catártica, o exame integraria a educação, mesmo que as eventuais demonstraçóes a que ele leve ainda tenham seu estatuto epistêmico sujeito a disputa. Soa entáo procedente a conclusão de que pensar bem é aprender a perguntar, a estabelecer com precisão os melhores termos para formular questôes justas e desenvolvê-las tendo como referência ideal o registro do que são verdadeiramente as coisas. Como ensina Dixsaut, "O filósofo, tal como Platão o concebe, não é sábio, tampouco detém a verdade, ele busca aquilo que, na verdade, é próprio do que é verdadeiramente. Aprender, examinar, buscar, interrogar e responder - não há e jamais houve para Platão outras modalidades de saber. Isso não faz do filósofo, no entanto, um ignorante, porque segundo ele ignorar não é o contrário de saber, mas sim crer que se sabe" (Dixsaut, 20I2, p. 84). Desta forma fica esclarecido por que o pior adversário da verdade não é a falsidade, mas a convicção. ${ }^{41}$

A noção de que os resultados obtidos mediante o exame socrático são por natureza discutíveis, vale dizer, sempre passíveis de aperfeiçoamento, permite aos intérpretes retomar uma imagem do pensador na qual sua maneira de viver ganha grande relevo. Sob este enfoque, é plausível que os resultados filosóficos e vitais do trabalho sejam apurados de preferência junto ao processo dialógico em andamento e não junto aos produtos por ele colhidos na forma de discursos prontos. ${ }^{42}$ Não se trata, a partir daí, de delinear um perfil psicológico da personagem, iniciativa condenada de saída por seu anacronismo, mas de, visando certa práxis, reconhecer seus componentes típicos, estimulando sua emulação. Nesse sentido, aliás, a divisa tomada de empréstimo ao culto a Apolo mostra todo seu alcance. Tentando conhecer Sócrates, meditando em seu exemplo, cada um recebe como contrapartida uma ocasiáo para o exercício de conhecer a si mesmo, como já foi dito antes. A incorporaçáo deste tema agora socrático implica as transformações na pauta da pesquisa que viemos assinalando desde o começo, requerendo antes de mais nada a conjugação entre as vertentes ética e teórica da pesquisa filosófica.

\footnotetext{
${ }^{41}$ A propósito disso: embora convencidos das vantagens da leitura de Dixsaut sobre a de Vlastos, como procuramos mostrar até aqui, não podemos deixar de considerar que a matéria está longe de uma formulaçáo definitiva. Para ficarmos num exemplo à mão, vale referir o artigo de Almeida Junior (2015), em que a revisão de certos aspectos das refutaçóes levadas a efeito no Górgias tende a favorecer as posiçóes defendidas por Vlastos a respeito do exame socrático.

${ }^{42}$ Cumpre mencionar a acerba polêmica a respeito da autonomia da escrita em Platão, baseada nas célebres observaçóes desenvolvidas no Fedro (275a-b, 276a-c e 277a) e no recurso a fontes indiretas do platonismo antigo. Náo nos compete deliberar sobre a prioridade ou não das "doutrinas náo escritas" sobre o corpus integrado pelos diálogos e pelas cartas, mas apenas assinalar que a estratégia de leitura preconizada por Trabattoni (2003), considerando cada diálogo como uma peça artística e filosoficamente autárquica, resulta numa via média bastante fecunda para a entrada no assunto.
} 
Já há alguns anos que, por iniciativa de Pierre $\operatorname{Hadot}^{43}$, propôs-se uma reavaliação do entendimento costumeiro acerca do que seria a filosofia antiga, em contraste com a atividade filosófica tal como esta se firmou entre nós, principalmente no ambiente universitário. Esta revisão historiográfica da filosofia das escolas do período helenístico dá a ver nelas, de modo probante, a radicalidade do compromisso entre vida e pensamento exigido de todos os que se conduzem a partir dele. De acordo com isso, não faz sentido adquirir os preceitos inerentes a qualquer das doutrinas escolares disponíveis sem que esse aprendizado se faça acompanhar do esforço em ajustar a própria conduta a eles. ${ }^{44}$ Mesmo que do modo mais requintado, saber o que dizem as fontes filosóficas sobre isso e aquilo não é ainda viver filosoficamente, não é ainda participar do espaço do saber, tendo já recusado a ignorância. O trabalho de paráfrase e restituição de argumentos, moeda corrente no ensino acadêmico que praticamos, tem grande valor propedêutico, mas não esgota os fins últimos da filosofia - que, na companhia de Sócrates, apontam para a conquista de uma vida boa, como temos reiterado.

O que mais impressiona nesse contexto é que cada uma das diversas correntes que vieram a compor o caudal do pensamento antigo reivindique como sua a legítima herança socrática. ${ }^{45}$ Contudo, segundo uma feliz analogia, tal impressão pode ser atenuada: todos já convivemos com famílias em que a geração dos filhos é formada por vários indivíduos íntegros que em nada se assemelham entre si. Diante disso, o problema socrático volta a se impor. Como reconhecer o autêntico e separálo do espúrio, se não existem parâmetros consensuais para tanto, textuais ou não? Como dotar o fenômeno de uma legibilidade abrangente, considerados os contrastes e incongruências a que ele parece levar? Haveria, em suma, um denominador comum entre os herdeiros, apto a reuni-los segundo traços compartilhados?

O retrato de Sócrates, pintado por Hadot em conformidade com estas perguntas, mostra três avatares do personagem aos quais sua elusiva presença pode ser remetida, com vistas à sua melhor compreensão. Antes de tudo, ele é tomado como mediador entre o ideal contemplativo da sabedoria e os negócios e interesses humanos que

${ }^{43}$ Leitor refinado de pensadores canônicos — para a atualidade da questão das relaçóes entre vida e pensamento, vale destacar sua familiaridade com as filosofias de Schopenhauer, Kierkegaard, Nietzsche, Wittgenstein e Foucault, erguida sob o pano de fundo de seu amplo conhecimento da filosofia antiga - Hadot responde pela renovação do interesse pelo helenismo entre o público em geral, principalmente, como adiantado acima, no que concerne à concepção da filosofia como modo de vida. A extensão do débito deste nosso exercício em relação às suas ideias pode ser aquilatada na leitura das páginas que se seguem.

${ }^{44}$ A esse respeito, veja-se, por exemplo, os ensaios "A história do pensamento helenístico e romano" e "A filosofia como maneira de viver", constantes da "Parte VI: A liçáo da filosofia antiga" de Exercícios espirituais e filosofia antiga (Hadot, 20I4).

${ }^{45}$ A relação é extensa: a influência socrática é direta sobre a Academia e, por conseguinte, alcança o pirronismo que depois aí se desenvolve; sobre o cinismo de Antístenes e Diógenes; sobre o Jardim de Epicuro e, finalmente, sobre a escola cirenaica de Aristipo. Por intermédio de Platáo, incide sobre o ensino e a pesquisa praticados no Liceu e repercute ainda sobre o estoicismo do Pórtico - neste último, sob Zenáo e depois Atenodoro. Pormenores sobre isso aparecem adiante. 
transcorrem na ordem da imanência. ${ }^{46}$ Assim caracterizado, este Sócrates recebe como signo distintivo a adesão ao movimento, à passagem, ao trânsito entre as duas instâncias indicadas. Sem pertencer exclusivamente a qualquer delas, o personagem precisa fornecer a seus parceiros motivação e justificativas convincentes para que também se ponham em movimento, aspirando a algo mais elevado que as conquistas mundanas que, segundo a maioria, bastam para conferir dignidade a suas realizaçóes.

A pista para o acesso a este primeiro avatar está na série de desdobramentos ensejada pela celebrada ironia socrática. ${ }^{47}$ De pronto, este procedimento conversacional e literário duplica o próprio Sócrates, permitindo separar o dito e o náo dito por ele conforme sentidos contrastantes, o mais repetido de todos sendo a derivaçáo da sabedoria da consciência de que não se sabe. Disso decorre, via emulação, a possibilidade de o interlocutor também se duplicar em outra direção, identificando-se com o Sócrates que se encontra em dúvida ao mesmo tempo em que se desprende de seu eu anterior, empanturrado de opinióes e certezas. O dispositivo que entra em ação no processo é a máscara, aparência que recobre um fundo ainda indeterminado e talvez nunca inteiramente determinável. ${ }^{48} \mathrm{O}$ desconforto e a admiração gerados pela admissão da dúvida são como que absorvidos pela máscara, permitindo a coexistência entre as duas circunstâncias: a de um que está mal satisfeito com sua ignorância e a de outro que intui uma saída para isso, deslumbrando-se com o cenário onde poderá doravante se movimentar com boa consciência.

No vocabulário corrente, essa conquista é chamada de distanciamento crítico. Por meio dela, o interlocutor de Sócrates pratica um recuo em relação a si mesmo, tendo percebido pela primeira vez que mesmo os pretensos dados da experiência efetiva têm espessura e que, por conseguinte, náo se entregam plenamente a quem se atém à sua feição visível, positiva. A visão do mundo e de si mesmo acontece sempre em perspectiva, e é promissor em termos cognitivos e vitais explorar a configuração daquelas que nos importam antes de concluir pela diferença absoluta entre aparência e essência, como pretendem tradiçóes hegemônicas ligadas ao socratismo. Pois pode ser que o que se entende como essência seja tão somente um arranjo extremamente fecundo, diga-se de passagem - elaborado a partir da seleção de mais e melhores aparências. Uma contraprova disso está em que é ainda no campo das

\footnotetext{
${ }^{46}$ Nas palavras de Hadot: "um mediador entre o ideal transcendente da Sabedoria e a realidade humana concreta" (20I4, p. 9I), ou simplesmente "entre a norma ideal e a realidade humana" (ibid., p. 92).

${ }^{47}$ Passando ao largo deste tema maior, nos contentaremos em restituir o encaminhamento proposto para ele pelo próprio Hadot. Suas consideraçóes se apoiam nas ocorrências do termo eironeia em Platão (República, 337a; Banquete, 216e5; Apologia, 38ar), Aristóteles (Ética a Nicômaco, IIo8 a 22; II27 a 22) e Teofrasto (Caracteres, parágrafo I), e numa pletora de textos de eruditos como Jaeger, Friedländer, Robin, Marrou e Hamann, além de recorrer a autores como Goethe, Nietzsche e Kierkegaard.

${ }^{48}$ Segundo Hadot, "Por se mascarar a si mesmo, Sócrates tornou-se o prosopon, a máscara, de personalidades que tiveram necessidade de se proteger atrás dele. Ele lhes deu ao mesmo tempo a ideia de se mascarar e a de tomar como máscara a ironia socrática. Existe aí um fenômeno extremamente complexo por suas implicaçóes literárias, pedagógicas e psicológicas" (2014, p. 95).
} 
metáforas visuais que se articula o outro da visão, aquilo que é invisível aos olhos mas inteiramente construído como um análogo seu, a forma ou ideia. ${ }^{49}$

Aquele fundo indeterminado do caráter e das ações socráticas é ilustrado magistralmente na imagem oferecida pelo mais duvidoso dentre seus admiradores, ainda segundo a versão de Platão. Ao declarar aos presentes no banquete, no diálogo de mesmo nome, que Sócrates é como um Sileno, escultura em forma de oratório, cuja aparência externa tosca, semelhante à dessas criaturas míticas, esconde um interior repleto de delicadas figuras devocionais, seu amante Alcibíades confirma a duplicação irônica do amado. ${ }^{50}$ Embora feio e mal arrumado, Sócrates mantém um vínculo crucial com a beleza, pois nela milita ao se dedicar à conquista da verdadeira sabedoria. A distância entre aparência externa e interna, em todo caso, pode ser atravessada por quem náo estranha as metamorfoses necessárias para começar a filosofar por si mesmo, que em geral implicam que ele se torne Sócrates, nem que seja só por algum tempo e em regime de transiçáo. O recuo diante de si mesmo, proporcionado pela identificação com o modelo aberto do mestre, prepara o salto e a imersão em um si mesmo tornado outro, finalmente livre para examinar seu entorno e inspecioná-lo até os confins de tudo o que merece ser sabido.

O próximo avatar, que simultaneamente expóe e dissimula os empenhos socráticos, é a figuração divina do amor, Eros, apresentado como filho da carência e do recurso, tal como na narração da personagem Diotima, sacerdotisa estrangeira responsável por instruir Sócrates nas questôes do amor. ${ }^{51}$ Não obstante a riqueza de seus expedientes de caça, o amante é incompleto, faltando-lhe exatamente a transformação ensejada pela integração ao amado. Este, num primeiro momento, encontra-se indiferente e sem iniciativa, recolhido em si mesmo. Mas as atençóes de seu pretendente logo revelam-lhe algo inesperado: em seu interior dormiam impulsos correspondentes, que terminam por incliná-lo a entregar-se às solicitaçóes do outro,

${ }^{49}$ Em seu luminoso Nós e os gregos, Brandão constata que “[...] na Grécia, prevalece a visão: idéia é uma forma que se vê; theoría, algo que se contempla; uma coisa de que se tem certeza é saphés, isto é, evidente; o que náo se entende é skoteinós, obscuro. E assim poderíamos descobrir outras metáforas, segundo as quais tudo o que se entende ou se sabe está na esfera da claridade (até mesmo uma voz, um discurso ou uma explicação, se inteligíveis, dizemos que são claros) [...]" (2002, p. 37).

${ }^{50} \mathrm{Ver} O$ banquete, 216d-217a, passagem em que o sólido e inconfundível Sócrates é visto sob nova luz, e sua tosca aparência exterior é contraposta à bela aparência interior pelo inclassificável Alcibíades. A pergunta deste ressoa até hoje: Quem pode dizer que conhece Sócrates?

${ }^{51}$ A narrativa platônica em foco ( $O$ banquete, 203a et seq.) não coincide com qualquer das variaçóes genealógicas do mito cronologicamente anteriores, salvo na consideraçáo de que Eros "Garante náo apenas a continuidade das espécies, mas a coesão interna do cosmo", pois, enquanto intermediário entre os deuses e os homens, "ele preenche o vazio, tornando-se, assim, o elo que une o Todo a si mesmo" (Brandão, I99I). Na versáo platônica, a iniciativa em direção ao outro parte da falta, uma vez que é carência - personificada como Pobreza quem surpreende Recurso, que adormece cheio de si, e engendra com ele o filho Eros. Para nós, diversamente, a aproximaçáo é buscada por quem abunda em energia, mesmo que a dinâmica erótica subsequente embaralhe os papéis. Afinal, quem não tem o que dar é passivo, demandando um despertar que só será provocado de fora. Uma analogia com o já aludido processo de semeadura parece viável aqui: a terra inerte será tornada fecunda em presença das sementes, que mobilizam nela as condiçóes para a germinação. Nenhuma das duas instâncias é fértil sozinha, embora as sementes possam ser plantadas em qualquer terreno, pois procuram sempre, graças à sua "programaçâo" interna, oportunidade para brotar. 
provando a vigência em si mesmo de uma incompletude e de uma disponibilidade semelhantes às do que o despertou. ${ }^{52}$ Nos acasos bem-sucedidos, isso instaura um intenso e exigente circuito de trocas, em que a fusão de um membro do par com o outro nunca é definitiva, mas sempre renovável. Eis, em tons um pouco ligeiros, a relação entre o sábio Sócrates e sua amada sabedoria, mas também a relação entre o erótico Sócrates e seus discípulos, que o encantam e sáo por ele encantados. O quanto cada uma das fases do processo traz consigo de fingimento, astúcia e entrega verdadeira só pode ser determinado caso a caso, dia a dia, diálogo a diálogo. É um enredo que se repete e se modifica a cada iniciaçáo filosófica, tanto quanto a cada iniciação amorosa.

O terreno está preparado para a oferta de uma terceira figuração de Sócrates, que lhe empresta os traços de outro mito, o do divino Dioniso. ${ }^{53}$ Dilaceramento e recomposição se alternam nas peripécias do deus, apontando para o último limite na trajetória do vivente. Lida de um ângulo mórbido, a história mostra que é preciso morrer para o mundo se se deseja um ressurgimento na plenitude do ser. Nestes termos, para rejeitar o círculo vicioso da repetição de opinióes sobre opiniốes, seria necessário afastar-se em definitivo de quem o pratica, instalando-se algures entre as formas imperecíveis. Do ponto de vista da adesão socrática à sua cidade, entretanto, a lição pode exibir um teor diferente. Está-se aqui, na praça pública, na casa de nossos anfitriôes ou no tribunal, e náo longe daqui, entre os bem-aventurados em suas ilhas. Se a circulação de perguntas e respostas, que se realimenta sem decisão definitiva à vista, ocorre num corpo a corpo de pessoa a pessoa, é com isso que devemos lidar. Não parece necessário remeter as aventuras do deus para um plano transcendente, uma vez que a destruição e a regeneração que nelas se narra podem muito bem se verificar em meio aos eventos experimentados durante a aquisição e o exercício de uma consciência filosófica. Se a reflexão sobre a morte é um experimento filosófico crucial, cabe considerar, tendo Sócrates como exemplo, que uma boa morte deve ser procurada em continuidade com uma boa vida. Ao que se saiba, a morte não é refutação nem negação da vida, mas um acontecimento que põe termo

52 Nas ambivalentes idas e vindas entre o Visconde de Valmont e a Presidenta de Tourvel, contadas por Laclos (1983) em As relaçóes perigosas, o processo de sedução é dissecado em todas as suas nuances. Cabe ao leitor decidir se Valmont levou a termo uma fria campanha de conquista ou se, ao contrário, foi tocado eroticamente por sua pretendida, ingressando numa relação que causará sua conversão amorosa. No contexto do romance, sendo amor ou náo o que acomete Valmont, seu destino é selado por meio de sua destruição. Da montanha ele teria descido ao vale da morte, levado por um amor de perdiçáo.

${ }^{53}$ Nos dizeres de Hadot, que apoia sua associaçấo entre Sócrates e o deus principalmente em passagens de O banquete, este Dioniso - cuja versão mitográfica seguida por Platão é a do filho de Zeus raptado, despedaçado, cozido e comido pelos titấs a mando de Hera, embora depois redivivo, por intervençáo direta de seu pai - deve ser figurado simultaneamente como "o deus da morte e da vida" e "o deus da tragédia e da comédia" (20I4, p. 125). O amor trágico pela vida é de tal ordem que até mesmo o insondável desfecho da trajetória dos mortais é motivo de gratidão. Teria se cumprido, assim, em Sócrates, um destino semelhante ao do deus, que compreende os movimentos de descida e elevaçáo integrados sem soluçấo de continuidade no plano da existência comum. Nesse sentido, "Um galo a Asclépio!" pode bem ser traduzido por "Sócrates morreu, viva Sócrates!” - e eis-nos aqui às voltas com ele. 
à vida de um corpo, de um organismo vivo — talvez apenas comparável, de forma simetricamente negativa, ao acontecimento da concepção ou geração. A vida segue seu curso em meio à atividade dos demais viventes, e é com ela e eles que vamos nos ocupar a seguir. ${ }^{54}$

\section{A morte de Sócrates}

$\mathrm{Na}$ entrada do Hades, Menipo e Cérbero travam um diálogo — viabilizado pelo fato de ambos pertencerem, cada um à sua maneira, à condição canina. ${ }^{55} \mathrm{O}$ primeiro pergunta ao outro como foi a chegada de Sócrates ao reino dos mortos, recebendo como resposta um relato inesperado. Ainda à distância, Sócrates mostrava-se imperturbável. Ao aproximar-se do abismo, porém, ele hesitou, perdeu a compostura e se abandonou a um choro barulhento, mostrando-se igual a quase todos que passam por ali. Ciente do vexame, ele se concentrou em seguida, adotando uma postura rígida e aparentemente indiferente, atento à impressão que poderia causar em quem estava por perto. Instado a comparar a descida do próprio Menipo à desse seu predecessor, o cão conta que apenas seu interlocutor de momento e seu mestre Diógenes cumpriram a travessia de forma voluntária e desassombrada, deixando os gemidos para os outros.

O apólogo permite reenquadrar algumas questóes já ventiladas. De longe, Sócrates parece mesmo posto em sossego, tal como o vemos nas cenas de sua morte retratadas por Platão. ${ }^{56}$ De perto, contudo, revelar-se-ia o postiço de sua atitude, autêntica apenas naqueles seus discípulos cínicos, que concluíram pela realidade natural e definitiva da morte, sem qualquer expectativa em relação à sobrevivência da alma em um estágio superior de existência. Sombras sorridentes, nada esperam e nada temem. Seria tudo isso mais uma indicaçáo a favor da hipótese de uma convergência de fundo entre Sócrates e Platáo, mostrando que o mestre ainda contava com um destino diferente da aniquilação, vislumbrado nas teorias e narrativas disseminadas nas páginas escritas por esse seu seguidor ${ }^{257}$ Com a concisão e finura características

\footnotetext{
${ }^{54}$ Um equacionamento análogo entre "o pensamento da vida" e "o pensamento da morte" é oferecido por Nietzsche no aforismo 278 de $A$ gaia ciência. Embora "a morte e seu silêncio" sejam "a única coisa certa e comum" no futuro de todos, o filósofo constata feliz "quanta fruição, quanta impaciência e cobiça, quanta sede e embriaguez de vida năo se manifestam a cada instante" (Nietzsche, 2009, p. 189). Parece-nos que o pensamento da morte, a realidade de sermos todos "irmáos na morte", pode funcionar como a maior libertação a favor de seu contrário. Os desenvolvimentos da seção seguinte ("4. A morte de Sócrates") buscarão elucidar esta implicação, cujos efeitos têm para nós valor conclusivo.

55 Este reconto está baseado no Diálogo IV dos Diálogos dos mortos, de Luciano de Samósata (2007). Ao trazer à baila esta obra deliciosa, nossa intençáo é reforçar a noçáo de que os mortos seguem acessíveis a nós, integrando um circuito, assimétrico mas náo descontínuo, que os liga aos vivos.

${ }^{56}$ Sócrates preso, à espera da execução, aparece no Críton (1997) e no Fédon (1987), tratando de dois temas correlatos, a saber, a conveniência de escapar da cadeia atendendo ao apelo dos amigos e, por extensão, se excluir do império das leis e da legalidade, e a possibilidade de se provar a imortalidade da alma, com todas as consequências morais e metafísicas daí decorrentes.

${ }^{57}$ As implicaçóes escatológicas da pretensa demonstração da imortalidade da alma são exploradas, por exemplo, no conto do mito de Er - guerreiro valente morto em combate, embora ressuscitado doze dias depois, a fim
} 
de sua prosa, Luciano sugere que sim, reservando exclusivamente para os membros da tradição cínica o triunfo sobre "a coisa", para eles somente mais uma parte dos processos soberanos da natureza. ${ }^{58}$

Como já foi reiterado, formas variadas de filosofar e de viver podem ser - e, com efeito, foram - derivadas do exemplo socrático. Um mapeamento não exaustivo, tomado de empréstimo a Hadot e outros ${ }^{59}$, mostra que ao menos seis tradiçóes filosóficas surgidas depois dele reivindicam sua herança sob diferentes aspectos pela ordem, os desdobramentos do platonismo em suas vertentes dogmática e cética, o aristotelismo em menor medida, as filosofias cirenaica e cínica, com as quais concorreram mais tarde o epicurismo e o estoicismo. Em algum grau, todas as escolas em atividade durante o período helenístico lidam com preocupaçóes que, em última análise, procedem da práxis de Sócrates. A par disso, como já aludido, o gênero dos diálogos socráticos floresceu de forma abundante em seguida ao desaparecimento do homem, atestando a força do apelo por sua conversáo em personagem, no intuito de fixar-lhe uma figura, senão verdadeira, ao menos verossímil. ${ }^{60}$ Nesse sentido, interessa ainda retomar o problema de Sócrates a partir das circunstâncias da morte do indivíduo, buscando nisso o resgate de sua feição derradeira. O propósito, vale enfatizar, é o estabelecimento de uma versão capaz de nos proporcionar um insight preciso quanto ao que tanto provocou admiração pública em relaçáo à atitude socrática em face da própria morte anunciada.

de narrar o que vira no além —, que consta do Livro x de A República. Num espírito um tanto ao quanto devocional, o mito vincula as escolhas do modelo de vida a ser conduzido pelas almas que vão entrar no mundo ao destino que cumprirão depois que saírem dele. Conclui Sócrates: "Referir todos os pormenores seria, ó Glaucon, tarefa para muito tempo. Mas o essencial, dizia ele, [Er], era o que se segue. Fossem quais fossem as injustiças cometidas e as pessoas prejudicadas, pagavam a pena de tudo isso sucessivamente, dez vezes por cada uma, quer dizer, uma vez em cada cem anos, sendo esta a duração da vida humana — a fim de pagarem, decuplicando-a, a pena do crime; por exemplo, quem fosse culpado da morte de muita gente, por ter traído Estados ou exércitos e os ter lançado na escravatura, ou por ser responsável por qualquer outro malefício, por cada um suportava padecimentos a decuplicar; e, inversamente, se tivesse praticado boas açóes e tivesse sido justo e piedoso, recebia recompensas na mesma proporçáo.” (Platão, I996, 6isa et seq.).

${ }^{58}$ Lê-se no diálogo referido: “- Menipo: Então o homem era um sofista e não era verdade que desprezava a coisa?! - Cérbero: Não. Mas, depois que ele viu que a coisa era para valer, ficou rígido de maneira a parecer que não era contra sua vontade que iria sofrer o que é absolutamente necessário sofrer; a fim de que os expectadores o admirassem. De um modo geral, eu poderia dizer o mesmo desse tipo de gente: até a entrada, eles parecem ousados e valentes; mas as coisas aqui dentro dão uma medida exata deles” (Luciano de Samósata, 2007, p. 63). O mais severo e imparcial metron revela o quanto cada vivente soube fazer render sua cota.

59 Ver, quanto ao passo, "A história do pensamento helenístico e romano", de Hadot (20I4b), bem como os capítulos "The socratic legacy", de Long (I999); "Epicurean ethics", de Erler (I999); e "Stoic ethics", de Inwood e Donini (1999).

${ }^{60} \mathrm{Ver}$, a respeito, o exaustivo mapeamento realizado por Rossetti (2015) em nome de uma hipótese interessantíssima: a proliferação de produçóes do gênero teria sido sistematicamente subestimada pela recepção, merecendo ser revista de ponta a ponta. Entre outras implicaçóes, o desenvolvimento de sua pesquisa sugere que a própria datação relativa ao nascimento da filosofia deveria ser reconsiderada, figurando Sócrates e os socráticos como os primeiros a serem literalmente identificados como filósofos. 
Há aqui, conforme já insistimos, uma proliferação das chances de apropriação do ponto. ${ }^{61}$ De uma parte, a grande maioria celebra a coragem com que Sócrates enfrenta o cumprimento de sua pena, extensão da coragem manifestada ao longo da vida como soldado, cidadáo e, sobretudo, pensador. Último ato de uma trajetória em tudo coerente, seu sereno encaminhar-se para o fim sugere a presença de uma confiança extrema quanto à significação daquilo tudo, do todo integral constituído por uma vida dignificada pelo exame.

Uma tal confiança pode ser entendida como sinal de que as esperanças do personagem o reasseguravam quanto a seu destino definitivo. Tendo percebido que as contingências existenciais não encerrariam em si o sentido ou o valor de uma vida, filosoficamente examinada ou náo, ele miraria um futuro após a morte em que sua alma, enfim liberada do consórcio com o corpo, persistiria no empenho esposado pela vida afora, estando agora em situação de contemplar plenamente aquilo que tinha até então apenas intuído. É um relato edificante, que aposta numa espécie de retorno da alma de Sócrates ao seio do ser verdadeiro, lugar de sua origem absoluta. As últimas palavras atribuídas por Platão ao personagem ${ }^{62}$, solicitando o resgate de uma dívida junto a Asclépio, parecem corroborar esta liçáo: somente aquele que visse na vida uma doença poderia desejar o pagamento por uma cura desse tipo. ${ }^{63}$

Uma via média faculta que se entenda de modo mitigado essa expectativa imputada ao personagem. Diante de seus juízes, Sócrates rebate a acusação de impiedade alegando ignorância inclusive quanto ao que o aguardava depois de morto. ${ }^{64}$ Se ele se pôs a serviço da divindade, fazendo render o que foi dito pelo oráculo ao se entregar ao exame racional, isso não implicaria qualquer certeza quanto aos fundamentos de sua prática, estando ele vivo ou morto. Seu destemor viria da confiança em que tinha empregado suas energias da melhor maneira possível, mesmo não dispondo de garantias metafísicas a esse respeito. O conhecimento dos desígnios divinos e das estruturas últimas do real não estaria à altura dos poderes da cognição

${ }^{61} \mathrm{O}$ alcance da exortaçáo socrática é quase sempre reforçado pelo relato de cena de sua morte e pela meditação que isso desperta. Um levantamento bastante completo, embora pouco aprofundado, das manifestaçôes artísticas e culturais referenciadas a esta morte foi feito por Wilson , que parte de uma alegaçáo incontornável: "Algumas histórias moldam a maneira das pessoas pensarem, sonharem e imaginarem. A morte de Sócrates teve um impacto imenso e por isso continua influenciando a cultura ocidental." (2013, p. 9).

${ }^{62}$ Lê-se no Fédon "Críton - exclamou ele - devemos um galo a Asclépio. Não te esqueças de saldar essa dívida!” (Platấo, 20II, II7e).

${ }^{63}$ Esta interpretação "alegórica" das últimas palavras de Sócrates é seriamente contestada pela leitura de Most (1993), que mediante raciocínio engenhoso e elegante sustenta a possibilidade de surpreendermos uma assinatura de Platáo oculta na passagem. Ausente da cena na prisáo, o autor do diálogo participa dela por meio de uma mençáo expressa ao fato de que esteve doente. Ora, isto autoriza a hipótese de que a dívida referida por Sócrates a uma cura já acontecida, e não por acontecer, remeteria a Platáo ele mesmo - e, por extensão, à filosofia socrática, que viverá por todo o tempo em que houver alguém lendo Platáo.

${ }^{64}$ Esta posição agnóstica é aventada, por exemplo, pelo Sócrates da Apologia: "Efetivamente, temer a morte, atenienses, não é mais que julgar ser sábio, sem o ser, porque é imaginar que se sabe o que não se sabe. É que ninguém sabe o que é a morte nem se, por acaso, ela será para o homem o maior dos bens. Mas temem-na como se soubessem com segurança que é o maior dos males. Não será esta ignorância mais censurável, julgar que se sabe o que não se sabe?” (Platão, I997, 29a). 
humana, que disporia com certeza apenas da consciência de seus limites. Constatada a partir da virtual equivalência entre todos os enunciados a respeito do que quer que seja, a ignorância conduziria coerentemente à suspensão do juízo, recurso que facultaria a conquista de uma tranquilidade em tudo humana, ótima companhia sob qualquer condição. Esta modéstia cognitiva e epistêmica caracteriza uma recepção ao mesmo tempo hedonista e cética dos ditos e feitos do personagem e lhe confere o caráter de precursor nestes caminhos. ${ }^{65}$ Diferenciaçóes doutrinais posteriores desembocarão, respectivamente, nas filosofias preconizadas por Aristipo e depois Epicuro, ${ }^{66}$ de uma parte, e de outra no magistério acadêmico, que evolui diretamente de Arcesilau a Pirro.

No polo oposto à posição inicial estão, por fim, os integrantes da já aludida linhagem de Antístenes e Diógenes. ${ }^{67}$ Comprometidos, como todos os demais socráticos, com a vida boa como finalidade prioritária da ação, seguem buscando articular razão e excelência prática, tendo a sabedoria como virtude mais alta. Sua versão a respeito dela, no entanto, é drasticamente deflacionada. Atendo-se ao plano da experiência direta, propóem a independência de julgamento, o domínio de si e a crítica da moralidade convencional como diretrizes principais de seu treinamento filosófico. Mas, mais do que isso, decidem sobre aquilo mesmo que a via cética recusa, oferecendo no mesmo movimento um contraponto de outra ordem a Platáo. Convencidos pela experiência comum de que nada sobrenatural nos espera após a morte, sustentam caber ao vivente, se pretende ser feliz, uma trajetória rigorosamente conforme à natureza. ${ }^{68} \mathrm{O}$ rigor na atenção ao corpo e às suas funçóes naturais só encontra paralelo no rigor preconizado posteriormente pelo estoicismo, embora a natureza

${ }^{65}$ Firmemente ancorada no relato de seu confrade Xenofonte, a historiadora Claude Mossé elabora o ponto em termos semelhantes a esse: "Será que Sócrates se entregou, no dia da sua morte, à sábia demonstração que Platâo lhe atribui e onde se encontram os temas desenvolvidos em outros lugares, principalmente na República? Pode-se duvidar disso. Mas que persuadido de que a morte é um longo sono e que alcançado o fim de sua vida ele nấo tinha que temê-la e por isso a tenha enfrentado com a coragem que a tradiçáo nos transmitiu, deve-se acreditar nisso" (1990, p. 136).

${ }^{66}$ Maiores esclarecimentos sobre o ponto encontram-se na seção II, “The socratic presence in greek ethics", do capítulo já referido, "The socratic legacy", devido a Long (I999, p. 6I8 et seq.).

${ }^{67}$ A primeira frase da Introduçáo ao alentado volume Os cínicos: o movimento cínico na antiguidade e seu legado diz que "O cinismo foi provavelmente a ramificaçáo mais original e influente da tradição socrática [...]".

${ }^{68}$ Em "A tradição socrática: Diógenes, Crates e a ética helenística", ao elencar as sete proposiçôes reconhecidamente defendidas pelo cinismo, Long (2007) situa no topo da lista aquela que afirma que "A felicidade é viver de acordo com a natureza". Quanto ao alinhamento entre os pensadores, lê-se que "Embora alguns epicuristas (mas talvez não o próprio Epicuro) fossem críticos de Sócrates, ele foi um precursor de Epicuro e de seu dedicado grupo de seguidores e o paradigma que ele proporcionou era o de alguém aperfeiçoado em suas próprias práticas. Os filósofos helenistas lidam intensivamente com o conceito de 'sábio', que já havia sido prefigurado pela hagiografia de Sócrates. Igualmente socrática e não aristotélica é a depreciação de valores convencionais, como riqueza ou renome público, e sua especificaçáo da felicidade em termos de liberdade, tranquilidade e autonomia. Esses fatores comuns são a promessa final de filosofias que chegam a uma agenda compartilhada por diferentes rotas e envolvem diferentes apreciaçôes de valores particulares. Contudo, claramente faz sentido distinguir todos eles da ética mais conservadora de Aristóteles e Teofrasto" (ibid., p. 620, traduçáo nossa). 
seja pensada de forma inteiramente diferente por esta escola, que a dota de significação racional transcendente e extrai daí uma série de orientaçóes filosóficas divergentes das adotadas pelo cinismo. ${ }^{69}$

Em todo caso, o conteúdo que Luciano empresta às falas de um Diógenes recém chegado ao Hades é inequívoco. Constatada a insignificância das diferenças sociais e das contingências existenciais perante a igualação universal evidenciada pela morte, a ocupação com a vida como dom gratuito que convida a um cultivo intensivo seria a resposta mais estrita e risonha disponível para o vivente. Se, por um lado, a meditaçáo sobre a efemeridade de tudo o que vive mostra nossa fragilidade em escala cósmica, por outro ela conduz à derrisão todas as presunçóes associadas à vaidade. Tendo tomado consciência do caráter único de cada vida individual, daquilo que é exclusivo no conjunto de experiências que constituem a cota de qualquer um, alguém afinal pode tomar responsabilidades filosóficas e vitais atento ao instante, à sua condição presente, como filho polivalente da natureza. Finita, insignificante em relaçáo ao mundo, cada vida é rara, até mesmo excepcional, se considerada em si mesma. Nesses termos, o pensamento da morte se presta a libertar para uma vida autêntica, alheia à servidão voluntária a que se entrega a maioria, refém do mais que aborrecido jogo da opinião - servidão aos sucessos ou fracassos práticos, avaliados em geral desde o ângulo dos resultados, cujos índices são dinheiro, poder, fama e coisas do mesmo gênero. ${ }^{70}$

Autonomia, autodeterminação, criação de si — num balanço aproximado, eis o saldo mínimo da atitude de Sócrates perante a vida e a morte, passível de endosso por qualquer de seus pupilos. ${ }^{71}$ Os deveres abraçados são claros e a alegria em tentar

${ }^{69}$ Sem explicitar o mérito destas alegações, contentamo-nos em seguir Long, que condensa as intrincadas relações de "parentesco" entre as escolas da maneira que se segue: "De todas as rotas pelas quais a filosofia de Sócrates foi transmitida para o mundo helenístico, a seguida pelos cínicos foi a mais surpreendente e, em certos aspectos, a mais influente. O cínico Crates foi o primeiro professor, em Atenas, de Zenáo de Cítio, o fundador do estoicismo. Crates é descrito na tradição biográfica como 'um homem como o Sócrates da $M e-$ morabilia de Xenofonte' (D. L. 7, 2-3). Pode-se supor que os primeiros estóicos tenham propagado rapidamente tais histórias, determinados como estavam a associar seu fundador a Sócrates. Por essa razão eles tornaram pública a sucessão filosófica Sócrates, Antístenes, Diógenes, Crates, Zenão. No cânone estóico de santos e quase sábios, Sócrates e Diógenes formam um duo onipresente" (2007, p. 39).

${ }^{70}$ É o que lemos no primeiro diálogo dos mortos: pedindo a Pólux, que transita desimpedido entre os dois reinos, que leve um recado e Menipo, Diógenes diz: "Menipo, Diógenes está te convidando, caso as coisas na terra já estejam suficientemente zombadas por ti, que venhas para cá, para zombar muito mais. Na verdade, aí o riso ainda está incerto e frequente o refrão: 'Quem sabe com certeza das coisas de além-vida?' Aqui, no entanto, não cessarás de rir com segurança, como eu estou fazendo agora. Sobretudo porque tu vês os ricos, os sátrapas, os tiranos, agora táo rebaixados e insignificantes, reconhecidos apenas pela lamentação; isto é, que são uns poltróes e ignóbeis, enquanto ficam recordando das coisas lá de cima." E ainda: "E também aos belos e fortes: a Megilo, de Corinto e ao lutador Danoxenes, diga-lhes que aqui, entre nós, não há mais nem cabeleiras loiras, nem olhos azuis ou negros, nem faces rosadas, nem músculos tesos ou espáduas poderosas, mas sim crânios desprovidos de beleza, enfim, que tudo é só cinza" (Luciano, 2008, p. 46).

${ }^{71}$ Estando aceita a filiaçấo socrática do cinismo, cabe lembrar a figura de Demônax de Chipre como exemplo acabado dos desenvolvimentos possíveis desta versão do socratismo. Embora sua própria existência em carne e osso seja posta em dúvida por alguns, este personagem figura no Apêndice A de Os cínicos: o movimento cínico na antiguidade e seu legado, que consiste em "Um catálogo abrangente de filósofos cínicos conhecidos", 
cumpri-los prova que a adesão a eles é livre. Ora, o que fazer diante disso? É certo que Sócrates ultrapassou a morte de alguma maneira, chegando até nós como pensamento vivo, convite e estímulo ao exame. Tomando indiscriminadamente ficção literária e filosófica como modos possíveis de imortalidade, podemos inclusive dizer que a alma loquaz de Sócrates permanece conosco, tendo superado a dissolução de seu corpo. Ressalvando-se que, no espaço de tudo o que se escreveu a seu respeito, este corpo imprimiu marcas nesta alma, tornando indissociáveis a figura do personagem e seu lógos, temos na sua reputação, no que se diz dele, seu melhor presente. Meditar sobre o exemplo de Sócrates, tornar-se Sócrates, não é mais do que tornarse filósofo em nome próprio. ${ }^{72} \mathrm{E}$ quanto aos resultados disso, e quanto à filosofia que daí se depreende? Fiamo-nos ainda no que diz Nietzsche: que interessa a impressão alheia sobre o gosto dos seus frutos à árvore que os gerou $?^{73}$ Que sejam ocasiáo para outros cultivos e outras colheitas.

\section{Referências bibliográficas}

Adorno, F. (1990). Sócrates. Tradução de A. J. P. Ribeiro. Lisboa: Ediçóes 70.

ALMEIDA JÚNIOR, G. (I985). "Refutação da refutação: revivendo o élenkhos socrático segundo Gregory Vlastos”. In: Revista Classica, vol. 28 (2), pp. I27-I48.

ARISTÓfanes (1967). As nuvens. In: ARISTÓfanes, Sócrates. Tradução de G. M. Starzynski. São Paulo: DIFEL, pp. 46-58.

ASSUNÇÃO, T. R. (20I8). "Três figuras do mestre grego antigo". In: Boletim Enxame, n. 3. Disponível em http://jornadaebpmg.blogspot.com/2018/o6/enxame-3-5-ditos-e-escritos.html.

BrandĀO, J. L. (2002). "Nós e os gregos”. In: MARQues, H. (Ed.), Os gregos. Coleção Convite ao Pensar, Belo Horizonte: Autêntica/PUC Minas, pp. 29-44.

Brandão, J. (I9gI). Dicionário mítico-etimológico da mitologia grega. Vol. I, Petrópolis: Vozes.

Descartes, R. (2007). Discurso do método. Tradução de M. E. de A. Prado Galvão. São Paulo: Martins Fontes.

DiXsaut, M. (2012). "Refutação e dialética”. In: Marques, M. P. (Ed.), Refutação. Tradução de Janaína S. Mafra. São Paulo: Paulus, pp. 55-86.

devido a Goulet-Cazé (2007). A principal fonte para seu conhecimento é a estupenda "Vida de Demônax", relato feito por Luciano (20I5), constante da coletânea Biografia literária.

${ }^{72}$ Cumpre estar avisado sobre os riscos de semelhante emulação. Uma forte identificação imaginária com o personagem pode resultar quixotesca, fazendo quem investe nela embarcar numa ilusão parecida com a que levou muita gente ao hospício convencida de ser Napoleão. Para acompanhar uma divertida variaçáo do ponto, veja-se Leys (1993).

${ }^{73}$ Nas palavras do filósofo: "Mas, sim, com a necessidade com que uma árvore tem seus frutos, nascem de nós nossas ideias, nossos valores, nossos sins e nãos e ses e quês - todos relacionados e relativos uns aos outros, e testemunhas de uma vontade, uma saúde, um terreno, um sol. - Se vocês gostarão desses nossos frutos? Mas que importa isso às árvores! Que importa isso a nós, filósofos!... (Nietzsche, 1987, p. 2). 
DORION, L.-A. (2OII). "The rise and fall of the socratic problem”. In: MORRISON, D. R. (Ed.), The Cambridge Companion to Socrates. Cambridge: Cambridge University Press, pp. I-23.

Dorion, L.-A. (2006). Compreender Sócrates. Tradução de L. M. Endlich Orth. Petrópolis: Vozes.

ERler, M. (I999). "Epicurean ethics”. In: AlgrA, K. et al. (Eds.), The Cambridge History of Hellenistic Philosophy. Cambridge: Cambridge University Press, pp. 642-674.

GotTlieb, A. (1999). Sócrates: o mártir da filosofia. Tradução de I. Fernandes Franco. São Paulo: EdUNESP.

Goulet-CaZÉ, M. O. (2007). "Apêndice A: Um catálogo abrangente de filósofos cínicos conhecidos”. In: Goulet-Cazé, M. O. \& Branham, R. B. (Eds.), Os cínicos: o movimento cínico na Antiguidade e o seu legado. Tradução de C. C. Bartalotti. São Paulo: Loyola, pp. 419-444.

GRIMALdi, N. (2006). Sócrates, o feiticeiro. Tradução de N. N. Campanário. São Paulo: Loyola.

HADOT, P. (20I4). Exercícios espirituais e filosofia antiga. Tradução de F. F. Loque \& L. Oliveira. São Paulo: É Realizaçóes Editora.

InWOOD, B. \& Donini, P. (I999). "Stoic ethics". In: Algra, K. et al. (Eds.), The Cambridge History of Hellenistic Philosophy. Cambridge: Cambridge University Press, pp. 675-738.

LAClos, C. (1983). As relaçôes perigosas. Tradução de S. Milliet. São Paulo: Abril Cultural.

LeYs, S. (1993). A morte de Napoleão. Tradução de R. F. D’Aguiar. São Paulo: Schwarcz.

Long, A. A. (1999). "The socratic legacy". In: AlgrA, K. et al. (Eds.), The Cambridge History of Hellenistic Philosophy. Cambridge: Cambridge University Press, pp. 6I5-64I.

LONG, A. A. (2007). "A tradição socrática: Diógenes, Crates e a ética helenística". In: Os cínicos: o movimento cínico na Antiguidade e o seu legado. Tradução de C. Camargo Bartalotti. Sáo Paulo: Loyola, pp. 39-58.

LuCiano de SAmÓSATA (2007). Diálogos dos mortos. Tradução de H. G. Murachco. São Paulo: Edusp: Palas Atena.

LuCiANO DE SAMÓSATA (20I5). "Vida de Demônax". In: Biografia literária. Tradução de O. F. Junior. I. Belo Horizonte: Editora UFMG.

Mafra, J. S. \& Marques, M. P. (20I2) (Eds.). Refutação. São Paulo: Paulus.

MARTES, E. (20I3). A questâo socrática: uma introdução. Tradução de V. Sampaio. São Paulo: Odysseus. 
MatThews, G. B. (2009). "The Epistemology and Metaphysics of Socrates". In: The Oxford Handbook of Plato. Oxford: Oxford University Press.

Mossé, C. (I990). O processo de Sócrates. Tradução de A. Marques. Rio de Janeiro: Jorge Zahar.

Most, G. W. (1993). “A Cock for Asclepius”. In: The Classical Quarterly, vol. 43 (I), pp. 96-III.

NietzsChe, F. (1987). Genealogia da moral: um escrito polêmico. Tradução de P. C. de Souza. São Paulo: Brasiliense.

Nietzsche, F. (2009). A gaia ciência. Tradução de P. C. de Souza. Sáo Paulo: Companhia das Letras.

PIETTRE, B. (1996). A República: Livro VII. Tradução de E. M. Marcelina. Brasília: UnB.

Platão (1973). Phaedrus \& The Seventh and Eighth Letters. Tradução de W. Hamilton. London: Penguin Books.

Platão (1987). Fédon, In: Platão. Platão. Tradução de J. Paleikat e J. C. Costa. São Paulo: Nova Cultural (Coleção Os Pensadores), pp. 55-26I.

Platão (1996). A República. Tradução de M. H. da Rocha Pereira. Lisboa: Calouste Gulbenkian.

Platão (1997). Apologia de Sócrates; Criton. Tradução de M. de Oliveira Pulquério. Brasília: UnB.

PlatÃo (I999). O banquete. Tradução de J. Cavalcanti de Souza. Rio de Janeiro: Bertrand Brasil.

Platão (20II). Fédon. Tradução de C. A. Nunes. Belém: EdufPa.

Platão (20I5). Laques/Eutífron. Tradução de C. A. Nunes. $3^{\text {a }}$ ed. Belém: EdUfPA.

Reale, G. \& Antiseri, D. (1990). História da filosofia. Vol. I. São Paulo: Paulus.

Rossetti, L. (20I5). O diálogo socrático. Tradução de J. Mafra. São Paulo: Paulus.

Rowe, C. (20II). "Self-examination”. In: The Cambridge Companion to Socrates. Cambridge: Cambridge University Press, pp. 2OI-2I4.

TAYLOR, C. W. (20IO). Sócrates. Tradução de M. Hack. Porto Alegre: L\&PM.

Trabattoni, F. (2003). Oralidade e escrita em Platão. Tradução de F. R. Puente e R. Bolzani. São Paulo: Discurso Editorial.

VILlA, D. (200I). Socratic citizenship. Princeton: Princeton University Press.

Vlastos, G. (20I2). "O elénkhos socrático: método é tudo". In: MAFra, J. S. \& Marques, M. P. (Eds.), Refutação. São Paulo: Paulus.

Wilson, E. (20I3). A morte de Sócrates. Tradução de F. Siqueira. Rio de Janeiro: Record.

WOLfF, F. (1982). Sócrates: o sorriso da razão. Tradução de F. Leopoldo e Silva. São Paulo: Brasiliense. 
XENOfONTE (1987). “Ditos e feitos memoráveis de Sócrates”. In: Sócrates. Tradução de L. R. de Andrade. São Paulo: Nova Cultural, pp. 59-I84.

Xenofonte (20II). Banquete; Apologia de Sócrates. Tradução de A. E. Pinheiro. São Paulo: Annablume. 